\author{
M.T. Kosmakova ${ }^{1}$, A.O. Tanin ${ }^{1}$, Zh.M. Tuleutaeva ${ }^{1,2}$ \\ ${ }^{1}$ Ye.A. Buketov Karaganda State University, Kazakhstan; \\ ${ }^{2}$ Karaganda State Technical University, Kazakhstan \\ (E-mail: Svetik_mir69@mail.ru)
}

\title{
Constructing the fundamental solution to a problem of heat conduction
}

\begin{abstract}
In this article, we discuss auxiliary initial-boundary value problems which will subsequently be used to solve boundary-value problem of heat conduction with axial symmetry in a degenerating domain. One of the problems is posed with homogeneous boundary conditions in order to construct a fundamental solution that is used to determine thermal potentials. The initial condition contains the Dirac function. The solution to the problems is found explicitly using the Laplace integral transformation. The boundary value problem is also considered in the absence of axial symmetry. It is shown that this problem splits into families of boundary-value problems similar to the problems considered above. In conclusion, we state the boundary value problem of heat conduction with axial symmetry in a degenerating domain, and its fundamental solution, found above, is written out.
\end{abstract}

Keywords: equation of heat conduction, fundamental solution, Laplace transformation, axial symmetry, Bessel equation.

\section{Introduction}

Problem I. In the domain $\Omega_{\infty}=\{(r, t): \quad 0<r<\infty ; t>0\}$ we consider the boundary value problem for equation

$$
\frac{\partial u}{\partial t}=\frac{a^{2}}{r} \frac{\partial}{\partial r}\left(r \frac{\partial u}{\partial r}\right)
$$

satisfying the boundary condition

$$
\begin{gathered}
\lim _{r \rightarrow 0+} \frac{u(r, t)}{\ln r}=-\varphi(t), t>0, \\
\lim _{r \rightarrow+\infty} u(r, t)=0,
\end{gathered}
$$

Problem II. In the domain $\Omega_{\infty}=\{(r, t): 0<r<\infty ; t>0\}$ we consider the boundary value problem for equation (1) under boundary conditions (2), (3) and and initial condition

$$
u(r, 0)=0, r>0 .
$$

It is known that equation (1) follows from the equation

$$
\frac{\partial u}{\partial t}=a^{2}\left(\frac{\partial^{2} u}{\partial x^{2}}+\frac{\partial^{2} u}{\partial y^{2}}\right)
$$

passing to polar coordinates.

Problem III. In a case without axial symmetry, we consider the following problem

in the domain

$$
\Omega_{1}=\{(r ; \alpha ; t): 0<r<t ; 0 \leq \alpha \leq 2 \pi ; 0<t<T\}
$$

find the solution to the equation

$$
\frac{\partial u}{\partial t}=a^{2}\left[\frac{1}{r} \frac{\partial}{\partial r}\left(r \cdot \frac{\partial u}{\partial r}\right)+\frac{1}{r^{2}} \frac{\partial^{2} u}{\partial \alpha^{2}}\right]
$$


satisfying the boundary conditions

$$
\begin{gathered}
\lim _{r \rightarrow 0+} \frac{u(r, \alpha, t)}{\ln (1 / r)}=u_{0}(t) ; 0<t<T, \\
\lim _{r \rightarrow t-} u(r, \alpha, t)=\left.u_{1}(\alpha ; t) \equiv u_{c}(x ; y ; t)\right|_{\sqrt{x^{2}+y^{2}}=t} ;(\alpha ; t) \in \partial \Omega_{1},
\end{gathered}
$$

where $\partial \Omega_{1}$ is the lateral surface of the cone.

Earlier $[1-4]$ we studied a homogeneous problem for the heat equation in the angular domain $G=\{(x ; t): t>0,0<x<t\}$ (as the domain $\Omega)$ :

find a solution to the heat equation

$$
\frac{\partial u}{\partial t}=a^{2} \frac{\partial^{2} u}{\partial x^{2}}
$$

satisfying the boundary conditions:

$$
\left.u(x, t)\right|_{x=0}=0,\left.\quad u(x, t)\right|_{x=t}=0 .
$$

In the work [5] in the domain $G$ the boundary-value problem of a homogeneous heat equation with boundary conditions:

was considered.

$$
\left.\frac{\partial u}{\partial x}\right|_{x=0}=0,\left.\frac{\partial u}{\partial x}\right|_{x=t}=0
$$

Solving the boundary value problems was reduced to solving the Volterra integral equation of the second kind with a kernel

$$
K(t, \tau)=\frac{1}{2 a \sqrt{\pi}}\left\{\frac{t+\tau}{(t-\tau)^{\frac{3}{2}}} \exp \left(-\frac{(t+\tau)^{2}}{4 a^{2}(t-\tau)}\right)+\frac{1}{(t-\tau)^{\frac{1}{2}}} \exp \left(-\frac{t-\tau}{4 a^{2}}\right)\right\} .
$$

It is shown that the kernels of the obtained integral equations are "incompressible", that is, the norm of the integral operator acting in the class of continuous functions is equal to unity. By the Carleman-Vekua method, solving the integral equation was reduced to solving the nonhomogeneous Abel equation. The explicit form of the solution of the integral equation has allowed to estimate the solution to the posed boundary value problem and precisely to determine the uniqueness classes of the solution to the posed homogeneous problem.

In [6], along with the direct problem, the conjugate boundary-value problem for the heat equation in the weighted functional class was also studied, and it was established that the posed boundary value problem is Noetherian problem.

We also note that boundary value problems for a spectrally loaded parabolic equation reduce to this kind of singular integral equations, when the load line moves according to the law $x=t[7-11]$ and problems for essentially loaded equation of heat conduction [12].

In all works, the boundary of the domain moves at a constant velocity. Attempts to study the solvability of boundary value problems for the heat equation in non-cylindrical domains with a variable velocity of changing the boundary were made in works [13-14].

In works [15-17] the second-order Volterra singular integral equation with the above kernel $K(t, \tau)$ is investigated. The multiplicity of eigenvalues and eigenfunctions for the Volterra integral operator is determined depending on the value of the spectral parameter and its spectrum is found.

In this paper, assuming that the isotropy property is fulfilled in the angular coordinate (axial symmetry), we study the problem for the heat equation in polar coordinates, to which the two-dimensional problem in the spatial variable is reduced.

In [18], the two-dimensional Dirichlet problem for the heat equation with respect to the spatial variable in an infinite dihedral angle was also considered. Using the Fourier transformation, the problem was reduced to a one-dimensional boundary value problem with the parameter.

Now we are studying the boundary value problem for the heat equation in the cone. To construct a solution to the problem we consider two auxiliary problems I and II.

The problem I solved in paragraph 1 is necessary to construct a fundamental solution, which will be further used in determining the thermal potentials. The solution to the original problem will be further presented as a sum of thermal potentials. 
The solution $u_{1}(r, t)$ to problem II found in paragraph 2 is used in the integral representation of the original problem to annul the boundary condition at the boundary $x=0$. In paragraph 3 , we have formulated a result that follows from the contents of paragraphs 1 and 2 .

In paragraph 4, a boundary value problem is considered in the absence of axial symmetry that is problem III. It is shown that this problem splits into families of boundary-value problems similar to the problem considered in paragraph 1.

\section{Function of the thermal instantaneous point source}

We will seek its solution in the class of originals of the Laplace transformation with respect to the variable $t$, depending on the parameter $r, r>0$.

We introduce the notation for the Laplace image: $L[u(r, t)]=\bar{u}(r, p)$.

As a result of applying the transformation to the equation (1):

$$
u_{t}=\frac{a^{2}}{r}\left(u_{r}+r u_{r r}\right)=\frac{a^{2}}{r} u_{r}+a^{2} u_{r r}
$$

taking into account the property of the Laplace transformation:

$$
u_{t} \div p \bar{u}(r, p)-u(r, 0)
$$

and to conditions (2) and (3), we obtain in the domain $\{r, r>0\}$ the boundary-value problem for the ordinary differential equation:

$$
\begin{gathered}
\frac{d^{2} \bar{u}}{d r^{2}}+\frac{1}{r} \frac{d \bar{u}}{d r}-\frac{p}{a^{2}} \bar{u}=-\frac{\delta\left(r-r_{0}\right)}{a^{2} r}, \\
\lim _{r \rightarrow 0+} \frac{\bar{u}(r, p)}{\ln r}=-\bar{\varphi}(p) \\
\lim _{r \rightarrow+\infty} \bar{u}(r, p)=0 .
\end{gathered}
$$

The homogeneous equation corresponding to equation (5) as a result of the replacement: $z=\frac{\sqrt{p}}{a} r$ is transformed to a modified Bessel equation:

$$
\frac{d^{2} \bar{u}}{d z^{2}}+\frac{1}{z} \frac{d \bar{u}}{d z}-\bar{u}=0
$$

The solution of equation (8) has the form: ([1], formula 8.494(1))

$$
\overline{u_{h o m}}(z)=C_{1} I_{0}(z)+C_{2} K_{0}(z)
$$

where ([19], formula 8.447):

$$
I_{0}(z)=\sum_{n=0}^{\infty} \frac{\left(\frac{z}{2}\right)^{2 n}}{(n !)^{2}} ; K_{0}(z)=-\ln z I_{0}(z)+\sum_{n=0}^{\infty} \frac{z^{2 n}}{2^{2 n}(n !)^{2}} \psi(n+1)
$$

$\psi(z)=\frac{\Gamma^{\prime}(z)}{\Gamma(z)}$ is Euler psi-function.

The following asymptotic formulas and approximations hold [19]:

when $0<z<<1$

$I_{0}(z) \approx 1 ; K_{0}(z) \approx \ln \frac{2}{C z}, C \approx 0,57721 \ldots-$ Euler const.

when $z>>1$

$$
\begin{aligned}
& I_{0}(z)=\frac{e^{z}}{\sqrt{2 \pi z}}\left\{1+\frac{1}{8 z}+\frac{9}{128 z^{2}}+\left(\frac{1}{z^{3}}\right)\right\}
\end{aligned}
$$

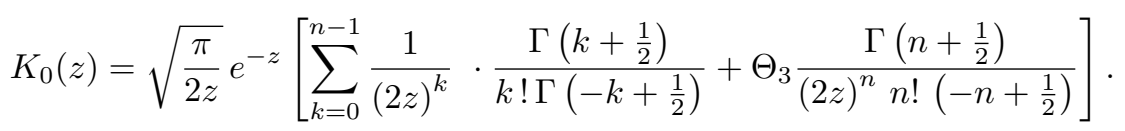

Here:

$\left|\Theta_{3}\right|<1$ and $\operatorname{Re} \Theta_{3} \geq 0$, when $\operatorname{Re} z \geq 0$; 
$\left|\Theta_{3}\right|<|c o \sec (\arg z)|$, when $\operatorname{Im} z=0$;

$0 \leq\left|\Theta_{3}\right| \leq 1$, when Rez $\geq 0$.

Returning to the variable $r$ in (9), we obtain the general solution of the homogeneous equation corresponding to the equation (5):

$$
\overline{u_{h o m}}(r, p)=C_{1} I_{0}\left(\frac{\sqrt{p}}{a} r\right)+C_{2} K_{0}\left(\frac{\sqrt{p}}{a} r\right) .
$$

Then, according to the method of variation of arbitrary constants, we write the general solution of equation (5) in the form:

$$
\bar{u}(r, p)=C_{1}(r) I_{0}\left(\frac{r \sqrt{p}}{a}\right)+C_{2}(r) K_{0}\left(\frac{r \sqrt{p}}{a}\right) .
$$

To determine the functions $C_{1}(r), C_{2}(r)$ we compose a system of equations:

$$
\left\{\begin{array}{l}
C_{1}^{\prime}(r) I_{0}\left(\frac{r \sqrt{p}}{a}\right)+C_{2}^{\prime}(r) K_{0}\left(\frac{r \sqrt{p}}{a}\right)=0 \\
C_{1}^{\prime}(r) \frac{d}{d r}\left(I_{0}\left(\frac{r \sqrt{p}}{a}\right)\right)+C_{2}^{\prime}(r) \frac{d}{d r}\left(K_{0}\left(\frac{r \sqrt{p}}{a}\right)\right)=\frac{\delta\left(r-r_{0}\right)}{r} .
\end{array}\right.
$$

After some simplifications, taking into account formula 8.486 from [19], we obtain:

$$
\left\{\begin{array}{l}
C_{1}^{\prime}(r) I_{0}\left(\frac{r \sqrt{p}}{a}\right)+C_{2}^{\prime}(r) K_{0}\left(\frac{r \sqrt{p}}{a}\right)=0 \\
-C_{1}^{\prime}(r) I_{1}\left(\frac{r \sqrt{p}}{a}\right)+C_{2}^{\prime}(r) K_{1}\left(\frac{r \sqrt{p}}{a}\right)=\frac{\delta\left(r-r_{0}\right)}{a r \sqrt{p}} .
\end{array}\right.
$$

By virtue of formula 8.477 (2) from [19], the determinant of this system is equal to:

$$
\Delta=I_{0}\left(\frac{r \sqrt{p}}{a}\right) K_{1}\left(\frac{r \sqrt{p}}{a}\right)+I_{1}\left(\frac{r \sqrt{p}}{a}\right) K_{0}\left(\frac{r \sqrt{p}}{a}\right)=\frac{a}{r \sqrt{p}} .
$$

Then the solution of the system takes the form:

$$
\begin{gathered}
C_{1}^{\prime}(r)=-\frac{\delta\left(r-r_{0}\right)}{a^{2}} K_{0}\left(\frac{r \sqrt{p}}{a}\right) ; \\
C_{2}^{\prime}(r)=\frac{\delta\left(r-r_{0}\right)}{a^{2}} I_{0}\left(\frac{r \sqrt{p}}{a}\right) .
\end{gathered}
$$

Integrating the last equalities, we obtain

$$
\begin{gathered}
C_{1}(r)=-\int_{r}^{+\infty} \frac{\delta\left(\xi-r_{0}\right)}{a^{2}} K_{0}\left(\frac{\xi \sqrt{p}}{a}\right) d \xi= \\
=C_{1}^{0}+\left\{\begin{array}{cc}
\frac{1}{a^{2}} K_{0}\left(\frac{r_{0} \sqrt{p}}{a}\right) ; & r<r_{0}, \\
0 ; & r>r_{0} .
\end{array}\right.
\end{gathered}
$$

and

$$
\begin{aligned}
& C_{2}(r)=\int_{0}^{r} \frac{\delta\left(\xi-r_{0}\right)}{a^{2}} I_{0}\left(\frac{\xi \sqrt{p}}{a}\right) d \xi= \\
& =C_{2}^{0}+\left\{\begin{array}{cc}
0 ; \quad r<r_{0} . \\
\frac{1}{a^{2}} I_{0}\left(\frac{r_{0} \sqrt{p}}{a}\right) ; & r>r_{0},
\end{array}\right.
\end{aligned}
$$

We substitute the found functions $C_{1}(r), C_{2}(r)$ into (10):

$$
\bar{u}(r, p)=C_{1}^{0} I_{0}\left(\frac{r \sqrt{p}}{a}\right)+C_{2}^{0} K_{0}\left(\frac{r \sqrt{p}}{a}\right)+\bar{G}\left(r, r_{0}, p\right),
$$

where

$$
\bar{G}\left(r, r_{0}, p\right)=\left\{\begin{array}{l}
\frac{1}{a^{2}} K_{0}\left(\frac{r \sqrt{p}}{a}\right) I_{0}\left(\frac{r \sqrt{p}}{a}\right) ; 0<r<r_{0} \\
\frac{1}{a^{2}} I_{0}\left(\frac{r \sqrt{p}}{a}\right) K_{0}\left(\frac{r \sqrt{p}}{a}\right) ; r_{0}<r<\infty
\end{array}\right.
$$


Now we will define the values of the constants. Let be $\forall p: R e p>0$.

Then, by virtue of asymptotic formulas and approximations, we have:

$$
r \rightarrow+\infty \Rightarrow\left\{\begin{array}{l}
I_{0}\left(\frac{\sqrt{p} r}{a}\right) \rightarrow+\infty \\
K_{0}\left(\frac{\sqrt{p} r}{a}\right) \rightarrow 0 .
\end{array}\right.
$$

Therefore, to satisfy condition (7), it is necessary to set $C_{1}=0$.

When $r \rightarrow 0$ (at $\forall p: R e p>0$ ) we get

$$
\frac{I_{0}\left(\frac{r \sqrt{p}}{a}\right)}{\ln r} \rightarrow 0, \quad \frac{K_{0}\left(\frac{r \sqrt{p}}{a}\right)}{\ln r} \rightarrow-1
$$

From condition (6) we have

$$
\lim _{r \rightarrow 0} \frac{\bar{u}(r, p)}{\ln r}=\lim _{r \rightarrow 0+} \frac{C_{2}}{\ln r} \ln \left(\frac{2 a}{C \sqrt{p} r}\right)=-C_{2}=-\bar{\varphi}(p) .
$$

We have obtained a solution to problem (5) - (7)

$$
\bar{u}(r, p)=\bar{\varphi}(p) K_{0}\left(\frac{r \sqrt{p}}{a}\right)+\bar{G}\left(r, r_{0}, p\right) .
$$

By virtue of the formula [20], (p.241; formula No.117)

and

$$
L\left[\frac{1}{2 t} \cdot e^{-\frac{r^{2}}{4 a^{2} t}}\right]=K_{0}\left(\frac{r \sqrt{p}}{a}\right)
$$

$$
L\left[\frac{1}{2 t} \exp \left(-\frac{a+b}{2 t}\right) I_{0}\left(\frac{a-b}{2 t}\right)\right]=K_{0}(\sqrt{a p}+\sqrt{b p}) I_{0}(\sqrt{a p}-\sqrt{b p})
$$

when Rea $>$ Reb $>0$, after applying inverse Laplace transform to (11) and some simplifications, we obtain:

$$
u(r, t)=u_{1}(r, t)+\frac{1}{2 a^{2} t} \exp \left(-\frac{r^{2}+r_{0}^{2}}{4 a^{2} t}\right) \cdot I_{0}\left(\frac{r r_{0}}{2 a^{2} t}\right),
$$

where

$$
u_{1}(r, t)=\left(\frac{1}{2 t} \exp \left(-\frac{r^{2}}{4 a^{2} t}\right)\right) * \varphi(t)=\int_{0}^{t} \frac{\exp \left(-\frac{r^{2}}{4 a^{2}(t-\tau)}\right)}{2(t-\tau)} \varphi(\tau) d \tau .
$$

(12) is the solution to problem (1)-(3) and the initial condition

$$
u_{1}(r, 0)=\frac{\delta\left(r-r_{0}\right)}{r} ; 0<r<\infty, 0<r_{0}<+\infty,
$$

which is verified directly. For example, after replacement $z=\frac{r}{2 a \sqrt{t-\tau}}$ function (13) takes the form

$$
u_{1}(r, t)=\int_{\frac{r}{2 a \sqrt{t}}}^{\infty} \frac{1}{z} e^{-z^{2}} \cdot \varphi\left(t-\frac{r^{2}}{4 a^{2} z^{2}}\right) d z
$$

Then condition (2) can be written as

$$
\lim _{r \rightarrow 0} \varphi(t) \cdot \frac{1}{\ln r} \int_{\frac{r}{2 a \sqrt{t}}}^{\infty} \frac{e^{-z^{2}}}{z} d z=\lim _{r \rightarrow 0} \frac{\varphi(t)}{2 \ln r} E i\left(-\left(\frac{r}{2 a \sqrt{t}}\right)^{2}\right)=\varphi(t),
$$

because ([19], $8.214(1))$ from the representation

$$
E i(x)=C+\ln (-x)+\sum_{k=0}^{\infty} \frac{x^{k}}{k \cdot k !}
$$

we have

$$
\lim _{r \rightarrow 0} \frac{E i\left(-\left(\frac{r}{2 a \sqrt{t}}\right)^{2}\right)}{2 \ln r}=\lim _{r \rightarrow 0} \frac{\ln \frac{r}{2 a \sqrt{t}}}{\ln r}=1 .
$$




\section{The first boundary value problem for a semirestricted domain}

In the domain $\Omega_{\infty}=\{(r, t): 0<r<\infty ; t>0\}$ we consider the boundary value problem for equation (1) under boundary conditions (2)-(3). This problem occurs in the theory of a diffusion trace behind a drop and a solid particle.

We will seek its solution in the class of originals of the Laplace transform with respect to the variable $t$, depending on the parameter $r, r>0$. In this paragraph we use the results of paragraph 2 .

As a result, we get

$$
u_{1}(r, t)=\left(\frac{1}{2 t} \exp \left(-\frac{r^{2}}{4 a^{2} t}\right)\right) * \varphi(t)=\int_{0}^{t} \frac{\exp \left(-\frac{r^{2}}{4 a^{2}(t-\tau)}\right)}{2(t-\tau)} \varphi(\tau) d \tau
$$

(14) is the solution to problem (1)-(4) and this fact is verified directly.

\section{Main result}

From the contents of paragraphs 1 and 2, the following theorem is proved.

Theorem. The function

$$
u(r, t)=\int_{0}^{t} \frac{\exp \left(-\frac{r^{2}}{4 a^{2}(t-\tau)}\right)}{2(t-\tau)} \varphi(\tau) d \tau+\frac{1}{2 a^{2} t} \exp \left(-\frac{r^{2}+r_{0}^{2}}{4 a^{2} t}\right) \cdot I_{0}\left(\frac{r r_{0}}{2 a^{2} t}\right),
$$

where $\varphi(t)$ is a continuous function for $t \in(0,+\infty)$ and $|\varphi(t)| \leq M t^{-1}$, const $M>0$, is the solution to the problem (1)-(4).

\section{Case without axial symmetry}

In the domain

$$
\Omega_{1}=\{(r ; \alpha ; t): 0<r<t ; 0 \leq \alpha \leq 2 \pi ; 0<t<T\}
$$

find the solution to the equation

$$
\frac{\partial u}{\partial t}=a^{2}\left[\frac{1}{r} \frac{\partial}{\partial r}\left(r \cdot \frac{\partial u}{\partial r}\right)+\frac{1}{r^{2}} \frac{\partial^{2} u}{\partial \alpha^{2}}\right]
$$

satisfying the boundary conditions

$$
\begin{gathered}
\lim _{r \rightarrow 0+} \frac{u(r, \alpha, t)}{\ln (1 / r)}=u_{0}(t) ; 0<t<T \\
\lim _{r \rightarrow t-} u(r, \alpha, t)=\left.u_{1}(\alpha ; t) \equiv u_{c}(x ; y ; t)\right|_{\sqrt{x^{2}+y^{2}}=t} ;(\alpha ; t) \in \partial \Omega_{1},
\end{gathered}
$$

where $\partial \Omega_{1}$ is the lateral surface of the cone.

To the boundary problem (15)-(17) we apply the Fourier method (the method of separation of variables). We seek the desired solution $u(r, \alpha, t)$ in the form

$$
u(r, \alpha, t)=U(r, t) \theta(\alpha)
$$

Substituting (18) into (15) we get

$$
\theta(\alpha) \cdot U_{t}=a^{2}\left[\frac{1}{r}\left(r \cdot U_{r}\right)_{r}^{\prime} \cdot \theta(\alpha)+\frac{1}{r^{2}} U \cdot \theta^{/ /}(\alpha)\right]
$$

or

$$
\frac{r^{2}}{a^{2}} \cdot \frac{U_{t}-\frac{a^{2}}{r}\left(r \cdot U_{r}\right)_{r}^{\prime}}{U}=\frac{\theta^{/ /}(\alpha)}{\theta(\alpha)}=-\lambda
$$

where $\lambda$ is a non-negative const. 
We get the system of differential equations

$$
\left\{\begin{array}{l}
\theta^{/ /}(\alpha)+\lambda \theta(\alpha)=0 \\
U_{t}-\frac{a^{2}}{r}\left(r \cdot U_{r}\right)_{r}^{\prime}+\frac{a^{2} \lambda}{r^{2}} U=0
\end{array}\right.
$$

The solution to the spectral problem

$$
\left\{\begin{array}{l}
\theta^{/ /}(\alpha)+\lambda \theta(\alpha)=0 \\
\theta(0)=\theta(2 \pi)
\end{array}\right.
$$

is a system of orthonormal eigenfunctions and eigenvalues

$$
\theta_{n}(\alpha)=\frac{1}{\sqrt{2 \pi}} \exp (i n \alpha) ; \lambda_{n}=n^{2} ; n \in Z .
$$

The solution to problem (15)-(17) has the form

$$
u(r, \alpha, t)=\sum_{n \in Z} U_{n}(r, t) \cdot \theta_{n}(\alpha)
$$

When $\lambda_{n}=n^{2}$ for the second equation of the system (19) we obtain

$$
\frac{\partial U_{n}}{\partial t}-\frac{a^{2}}{r} \frac{\partial}{\partial r}\left(r \cdot \frac{\partial U_{n}}{\partial r}\right)+\frac{a^{2} n^{2}}{r^{2}} U_{n}=0
$$

For the function (21) we apply the condition (16):

$$
\lim _{r \rightarrow 0}\left[\frac{U_{0}(r, t)}{\ln (1 / r)}+\sum_{n \in \mathbb{Z} \backslash\{0\}} \frac{U_{n}(r, t) \cdot \theta_{n}(\alpha)}{\ln (1 / r)}\right]=u_{0}(t) .
$$

Expanding the function $u_{0}(t)$ in a Fourier series on the eigenfunctions $\theta_{n}(\alpha)$, we obtain

$$
u_{0}(t)=\sum_{n \in Z} c_{n}(t) \cdot \theta_{n}(\alpha)
$$

where

$$
c_{n}(t)=\int_{0}^{2 \pi} u_{0}(t) \cdot \theta_{n}(\alpha) d \alpha
$$

From here we get the condition for the unknown functions $U_{n}(r, t), \quad n \in \mathbb{Z}$ :

$$
\begin{gathered}
\lim _{r \rightarrow 0} \frac{U_{0}(r, t)}{\ln (1 / r)}=u_{0}(t) ; \\
\lim _{r \rightarrow 0} \frac{U_{n}(r, t)}{\ln (1 / r)}=0, \quad n \in \mathbb{Z} \backslash\{0\}
\end{gathered}
$$

For the function (21) we apply the condition (17):

$$
\lim _{r \rightarrow t} u(r, \alpha, t)=\lim _{r \rightarrow t} \sum_{n \in Z} U_{n}(r, t) \cdot \theta_{n}(\alpha)=u_{1}(\alpha, t) .
$$

Expanding the function $u_{1}(\alpha, t)$ in a Fourier series on the eigenfunctions $\theta_{n}(\alpha)$, we obtain

$$
u_{1}(\alpha, t)=\sum_{n \in Z} u_{1 n}(t) \cdot \theta_{n}(\alpha)
$$

where

$$
u_{1 n}(t)=\int_{0}^{2 \pi} u_{1}(\alpha, t) \cdot \theta_{n}(\alpha) d \alpha
$$


Then from the equality

$$
\sum_{n \in Z}\left(\lim _{r \rightarrow t} U_{n}(r, t)\right) \cdot \theta_{n}(\alpha)=\sum_{n \in Z} u_{1 n}(t) \cdot \theta_{n}(\alpha)
$$

we get one more condition for the unknown functions $U_{n}(r, t), \quad n \in \mathbb{Z}$

$$
\lim _{r \rightarrow t} U_{n}(r, t)=u_{1 n}(t),
$$

where the functions $u_{1 n}(t)$ are defined by equality (25).

We introduce the replacement of an unknown function $U_{n}(r, t), \quad n \in \mathbb{Z}$ by the formula

$$
U_{n}(r, t)=v_{n}(r, t) \exp \left\{-\frac{a^{2} n^{2}}{r^{2}} t\right\} .
$$

Then substituting replacement (27) into equation (22) and into conditions (23), (24) and (26), we obtain boundary value problems for determining a new unknown function $v_{n}(r, t)$ :

I. $n=0$.

$$
\begin{gathered}
\frac{\partial v_{0}}{\partial t}=\frac{a^{2}}{r} \frac{\partial}{\partial r}\left(r \cdot \frac{\partial v_{0}}{\partial r}\right), \\
\lim _{r \rightarrow 0} \frac{v_{0}(r, t)}{\ln (1 / r)}=u_{0}(t), \\
\lim _{r \rightarrow t} v_{0}(r, t)=u_{10}(t),
\end{gathered}
$$

where

$$
u_{10}(t)=\int_{0}^{2 \pi} u_{1}(\alpha, t) d \alpha
$$

II. $n \neq 0$.

$$
\begin{gathered}
\frac{\partial v_{n}}{\partial t}=\frac{a^{2}}{r} \frac{\partial}{\partial r}\left(r \cdot \frac{\partial v_{n}}{\partial r}\right), \\
\lim _{r \rightarrow 0} \frac{v_{n}(r, t)}{\ln (1 / r)}=0, \\
\lim _{r \rightarrow t} v_{n}(r, t)=u_{1 n}(t)
\end{gathered}
$$

Thus, we have obtained a family of boundary value problems (28)-(30) and (31)-(33), each of which is a boundary problem of the form (1)-(3). The issues of solvability of these boundary-value problems will be investigated later.

Solving boundary value problems (28)-(30) and (31)-(33), we find functions $\left\{v_{n}(r, t), n \in \mathbb{Z}\right\}$, and further, using (20)-(21) and replacement (27), we formally construct a series

$$
u(r, \alpha, t)=\sum_{n \in \mathbb{Z}} v_{n}(r, t) \exp \left\{-\frac{a^{2} n^{2}}{r^{2}} t+i n \alpha\right\} .
$$

It is known that the series (formula 5.4.11.2 from [22], p.585):

$$
\sum_{n \in \mathbb{Z}} \exp \left\{-\frac{a^{2} n^{2}}{r^{2}} t+i n \alpha\right\},
$$

converges for $\forall t>0$.

Remark. The justification of the passage to the limit under the sign of the sum in all the series below follows from the uniform convergence of these series [21]. 


\section{Conclusion}

In the second part of the research, we solve the problem in the domain of degenerating to a point at the initial moment of time:

In the domain $\Omega=\{(r, t): 0<r<t ; t>0\}$ to find a solution to equation (1)

$$
\frac{\partial u}{\partial t}=\frac{a^{2}}{r} \frac{\partial}{\partial r}\left(r \frac{\partial u}{\partial r}\right)
$$

satisfying the boundary conditions (2)

$$
\lim _{r \rightarrow 0+} \frac{u(r, t)}{\ln r}=-\varphi(t), t>0
$$

and

$$
\lim _{r \rightarrow t-} u(r, t)=-\psi(t), t>0 .
$$

The function $G(r, \xi, t)=\xi G_{0}(r, \xi, t)$, where

$$
G_{0}(r, \xi, t)=\frac{1}{2 a^{2} t} \exp \left\{-\frac{r^{2}+\xi^{2}}{4 a^{2} t}\right\} \cdot I_{0}\left(\frac{r \xi}{2 a^{2} t}\right),
$$

is a fundamental solution to equation (1), $\xi$ is parameter. We note that this function was defined in Theorem. Thermal potentials will be preliminarily constructed using this fundamental solution.

Further, on the basis of the integral representation of the solution of the boundary value problem in the form of a sum of thermal potentials, we will reduce the study of the original problem to the study of the Volterra integral equation of the second kind, following [21] and [1-6].

\section{References}

1 Amangaliyeva, M.M., Dzhenaliev, M.T., Kosmakova, M.T., \& Ramazanov M.I. (2015). On one homogeneous problem for the heat equation in an infinite angular domain. Siberian Mathematical Journal, Vol. 56, No. 6, 982-995. DOI: 10.1134/S0037446615060038.

2 Jenaliyev, M., \& Ramazanov, M. (2016). On a homogeneous parabolic problem in an infinite corner domain. AIP Conference Proceedings, 1759, 020085. DOI: 10.1063/1.4959699.

3 Kosmakova, M.T., Ramazanov, M.I., Tokesheva, A.S., \& Khairkulova, A.A. (2016). On the non-uniqueness of solution to the homogeneous boundary value problem for the heat conduction equation in an angular domain. Bulletin of the Karaganda University. Series Mathematics, 4 (84), 80-87. DOI: 10.31489/2016M4 /80-87.

4 Amangaliyeva, M.M., Jenaliyev, M.T., Kosmakova, M.T., \& Ramazanov, M.I. (2015). Uniqueness and non-uniqueness of solutions of the boundary value problems of the heat equation. AIP Conference Proceedings, 1676, 020028. DOI: 10.1063/1.4930454.

5 Dzhenaliyev, M.T., Kalantarov, V.K., Kosmakova, M.T., \& Ramazanov, M.I. (2014). On the second boundary value problem for the equation of heat conduction in an unbounded plane angle. Bulletin of the Karaganda University. Series Mathematics, 4 (76), 47-56.

6 Jenaliyev, M., Amangaliyeva, M., Kosmakova, M., \& Ramazanov, M. (2014). About Dirichlet boundary value problem for the heat equation in the infinite angular domain. Boundary Value Problems, 213, 1-21. DOI: $10.1186 / \mathrm{s} 13661-014-0213-4$.

7 Jenaliyev, M.T., Iskakov, S.A., \& Ramazanov, M.I. (2017). On a parabolic problem in an infinite corner domain. Boundary Value Problems, 1 (85), 28-35. DOI: 10.31489/2017M1/28-35.

8 Amangaliyeva, M.M., Akhmanova, D.M., Dzhenaliev, M.T., \& Ramazanov, M.I. (2011). Boundary value problems for a spectrally loaded heat operator with load line approaching the time axis at zero or infinity. Differential Equations, 47, 2, 231-243. DOI: 10.1134/S0012266111020091.

9 Dzhenaliev, M.T., \& Ramazanov, M.I. (2006). On the boundary value problem for the spectrally loaded heat conduction operator. Siberian Mathematical Journal, 47, 3, 433-451. DOI: 10.1007/s11202-006-0056-z. 
10 Dzhenaliev, M.T., \& Ramazanov, M.I. (2007). On a boundary value problem for a spectrally loaded heat operator: I Differential Equations, 43, 4, 513-524. DOI: 10.1134/S0012266107040106.

11 Dzhenaliev, M.T., \& Ramazanov, M.I. (2007). On a boundary value problem for a spectrally loaded heat operator: II Differential Equations, 43, 6, 806-812. DOI: 10.1134/S0012266107060079.

12 Ramazanov, M.I., Kosmakova, M.T., Romanovsky, V.G., Zhanbusinova, B.H., \& Tuleutaeva, Z.M. (2018). Boundary value problems for essentially-loaded parabolic equation. Bulletin of the Karaganda University. Series Mathematics, 4 (92), 79-86. DOI: 10.31489/2018M4/79-86.

13 Akhmanova, D.M., Ramazanov, M.I., \& Yergaliyev. M.G. (2018). On an integral equation of the problem of heat conduction with domain boundary moving by law of $t=x^{2}$. Bulletin of the Karaganda University. Series Mathematics, 1 (89), 15-19. DOI: 10.31489/2018M1/15-19.

14 Kosmakova, M.T. (2016). On an integral equation of the Dirichlet problem for the heat equation in the degenerating domain. Bulletin of the Karaganda University. Series Mathematics, 1 (81), 62-67.

15 Amangaliyeva, M.M., Jenaliyev, M.T., Kosmakova, M.T., \& Ramazanov, M.I. On a Volterra equation of the second kind with 'incompressible' kernel. Advances in Difference Equations, 71, 1-14. DOI: 10.1186 /s13662-015-0418-6.

16 Amangaliyeva, M.M., Jenaliyev, M.T., Kosmakova, M.T., \& Ramazanov, M.I. (2014). On the spectrum of Volterra integral equation with the «incompressible» kernel. AIP Conference Proceedings, 1611, $127-132$. DOI: $10.1063 / 1.4893816$.

17 Akhmanova, D.M., Dzhenaliev, M.T., \& Ramazanov, M.I. On a particular second kind Volterra integral equation with a spectral parameter. Siberian Mathematical Journal, 52, 1, 1-10. DOI: 10.1134/S0037446 606010010 .

18 Kosmakova, M.T., Orumbayeva, N.T., Medeubaev, N.K., \& Tuleutaeva, Zh.M. (2018). Problems of Heat Conduction with Different Boundary Conditions in Noncylindrical Domains. AIP Conference Proceedings, 1997, UNSP 020071-1. DOI: 10.1063/1.5049065.

19 Gradshteyn, I.S., \& Ryzhik, I.M. (2007). Table of Integrals, Series, and Products. (7d ed.) AP: New York. USA.

20 Korn, G.A., \& Korn T.M. (2000). Mathematical Handbook for Scientists and Engineers. Dover Publications: Inc. Mineola. New York: USA.

21 Tikhonov, A.N., \& Samarskii, A.A. (2011). Equations of the mathematical physics. reprint edn., translated from the Russian by A.R.M Robson and P.Basu; Dover Publications: New York: USA.

22 Prudnikov, A.P., Brychkov, Yu.A., \& Marichev, O.I. N.M. (1998). Integrals and Series: Elementary Functions. (N.M.Queen, Trans) CRC: New York: USA.

\title{
М.Т. Космакова, А.О. Танин, Ж.М. Тулеутаева
}

\section{Бір жылуөткізгіштік есебінің фундаментальды шешімін құру}

\begin{abstract}
Мақалада осьтік симметриялы жойылатын облыстағы жылуөткізгіштіктің шеттік есептерін шығару үшін қолдануға болатын көмекші бастапқы-шеттік есептер талқыланған. Біртекті шекаралық шарттарымен қойылған есептердің біреуі жылу потенциалдарын анықтау үшін қолданатын фундаментальды шешімді құру үшін қойылған. Бастапқы шарты Дирак функциясын қамтиды. Есептің шешімі Лаплас интегралдық түрлендіруі көмегімен айқын түрде табылған. Сонымен қатар, осьтік симметрия болмаған жағдайдағы шеттік есеп қарастырылды. Бұл есеп жоғарыда қарастырылған ұқсас шекаралық есептердің шоғырына бөлінетіні көрсетілген. Қорытынды бөлімінде осьтік симметриялы жойылатын облыстағы жылуөткізгіштік шеттік есебінің қойылуы көрсетілген және оның жоғарыда табылған фундаментальды шешімі жазылған.
\end{abstract}

Kiлm сөздер: жылуөткізгіштік теңдеу, фундаментальды шешім, Лаплас түрлендіруі, осьтік симметрия, Бессель теңдеуі. 
М.Т. Космакова, А.О. Танин, Ж.М. Тулеутаева

\section{Построение фундаментального решения одной задачи теплопроводности}

В статье обсуждены вспомогательные начально-краевые задачи, которые впоследствии будут использованы для решения краевой задачи теплопроводности с осевой симметрией в вырождающейся области. Одна из задач с однородными граничными условиями поставлена для построения фундаментального решения, которое используется для определения тепловых потенциалов. Начальное условие содержит функцию Дирака. Решение задач найдено в явном виде с помощью интегрального преобразования Лапласа. Также рассмотрена краевая задача при отсутствии осевой симметрии. Показано, что эта задача разбивается на семейства краевых задач, аналогичных рассмотренным выше. В заключении приведена постановка краевой задачи теплопроводности с осевой симметрией в вырождающейся области и выписано ее фундаментальное решение, найденное выше.

Ключевые слова: уравнение теплопроводности, фундаментальное решение, преобразование Лапласа, осевая симметрия, уравнение Бесселя. 